\title{
The Representation of Meaning in POST-MillenNial ROCK ${ }^{1}$
}

\section{Walter Everett}

For millennia, philosophers and musicians have pondered the meaning of music. Since ancient consideration of art as mimesis, we have debated whether music has the ability to imitate, represent, or express or be expressive of, denote, depict, exemplify, refer to, signify, embody or possess the emotions; and whether it has rhetorical or semantic functions, or expresses any other extra-musical states or objects. As corollary concerns, we have spoken of the quality of metaphor; the roles of perception, cognition, and embodiment; the places of intentionality, imagination, arousal and catharsis in artist and perceiver, measures of the individual work against systematic convention and of appropriateness of interpretation; the competing values of order and complexity; and the special nature of hybrid arts such as the combination of words and music in song. The many publications that will be referred to in this essay represent only an entryway into a vast literature on these topics that spans centuries in a depth that has grown rapidly over the past quarter century. In short, those devoted to art in general and music in particular have long been driven to understand their representative meanings as precisely as possible from many perspectives.

Rock music of the past ten years has included a great deal of experimental work that exercises a strong interest in expressive uses of nonharmonic tones, competing tonal centers, and complex harmonic function that may be interpreted as underscoring such themes in the songs' poetic texts as paralysis, temptation, the consideration of alternatives, and cultural dehumanization. The goal of my essay is to examine a listener's con-

1 This essay is dedicated to the memory of both Rudolf Arnheim, whose teaching I was privileged to enjoy in 1981, and another of his students, Steve Larson, who did so much to bring the ideas of our teacher to the realm of music scholarship. The author is grateful to the musicologists of Princeton University and the music theorists of both Indiana University and the University of Michigan for opportunities to present and discuss there of some of the materials of this paper. 
sideration of the musical representations of these ideas in several recordings released after the year 2000, as contextualized by relevant philosophical and theoretical writings. Because the literature covering these many interrelated topics is so vast, a comprehensive survey of these writings in the space given here must often only skim the surface, and so this chapter will function largely as an outline of the topics addressed by existing scholarship, and a guide to the primary sources that treat them in detail.

l'd like to begin with Gestalt psychologist (and amateur violinist) Rudolf Arnheim. ${ }^{2}$ Arnheim holds that, in addition to an artwork's contours, it is essential to consider the dynamic tensions located within the work's skeletal axes. ${ }^{3}$ Such forces, shaped in music as gestures, are metaphorically isomorphic through cross-domain mapping with the dynamic properties that form the shape of underlying conceptualizations of bodily experience. We may examine Arnheim's axes of dynamic tension as seen in the visual arts through a series of illustrations. ${ }^{4}$ In Figure 1 we see on the left a trecento crucifixion (from the Orsini polyptych by Simone Martini, c. 1330, Koninklijk Museum voor Schone Kunsten, Antwerpen) and on the right a quattrocento rendering with the Virgin and St. John (the »London« Crucifixion, Antonello da Messina, 1475, National Gallery, London). The earlier painting emphasizes inhumanity, suffering, and death; the later one, redemption, grace, and life. Contours clarify the subjects, but Arnheim was more interested in the composition's structural forces than its outlines. As a first step, Figure 2 indicates the tense zig-zag structure of Christ's figure and the angular, faulted division of the crowd, suggestive of the earthquake described in Matthew 27:51-52, as envisioned by Martini. In the Antonello, gentle arcs and ovals suggest peace. In Figure 3, we add lines showing the directions of gazes, crucial for tracing the work's directed forces. These axes show a well balanced triangle on the right, but only a confusion of conflicting energies on the left. If we add emphasis to the lances and flag poles, as in Figure 4,

2 Arnheim's numerous books on the psychology of the arts include an understanding of music built on the stances of Eduard Hanslick, Carroll Pratt and Susanne Langer, and are sympathetic with writings by Victor Zuckerkandl, Mark Johnson, Steve Larson, Janna Saslaw, and Candace Brower in terms of embodied forces, and those by Marion Guck and Anthony Newcomb on metaphor. Unless specified otherwise, the reader is to understand all author citations as references to bodies of work by those writers explored in the articles and books listed in the appended »References « section. In most cases, particular cited passages should be understood as gateways to the larger discussions embodied by the entire writings that contain them.

3 See especially Arnheim 1966: 53-62; 1974: 11-15; and 1986: 214-227.

4 The brief analysis that follows is not from Arnheim, but is based on his principles. 
we see that the trecento image has become even more chaotic, especially in comparison to its placid companion. Schenkerians in particular would recognize a parallel between this analytical emphasis on structural dynamics, as opposed to surface contour, and the definition of linear progressions and other lines on which musical details are arranged in tonal music.
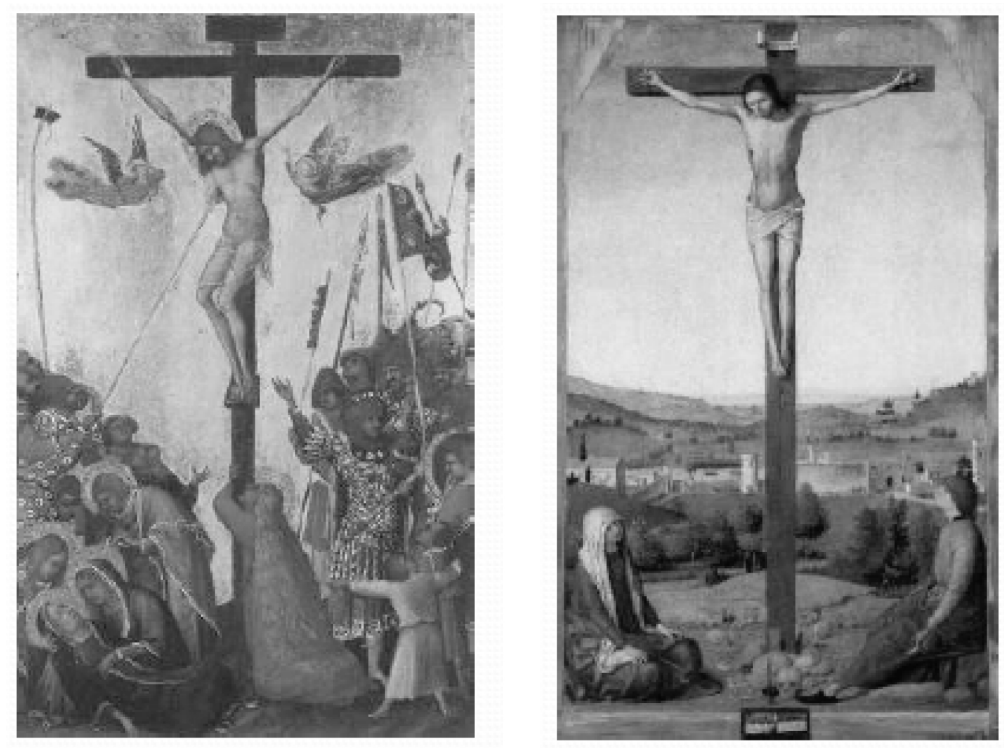

Figure 1: Crucifixion scenes as painted by Simone Martini (left) and Antonello da Messina (right)
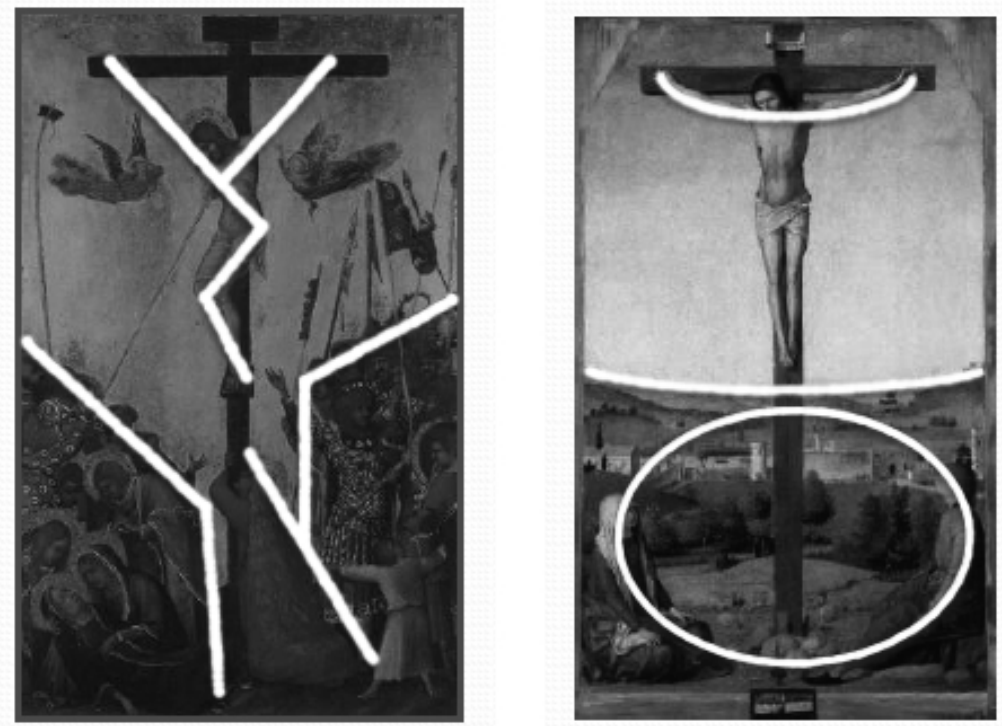

Figure 2: Lines mark general structural forces 

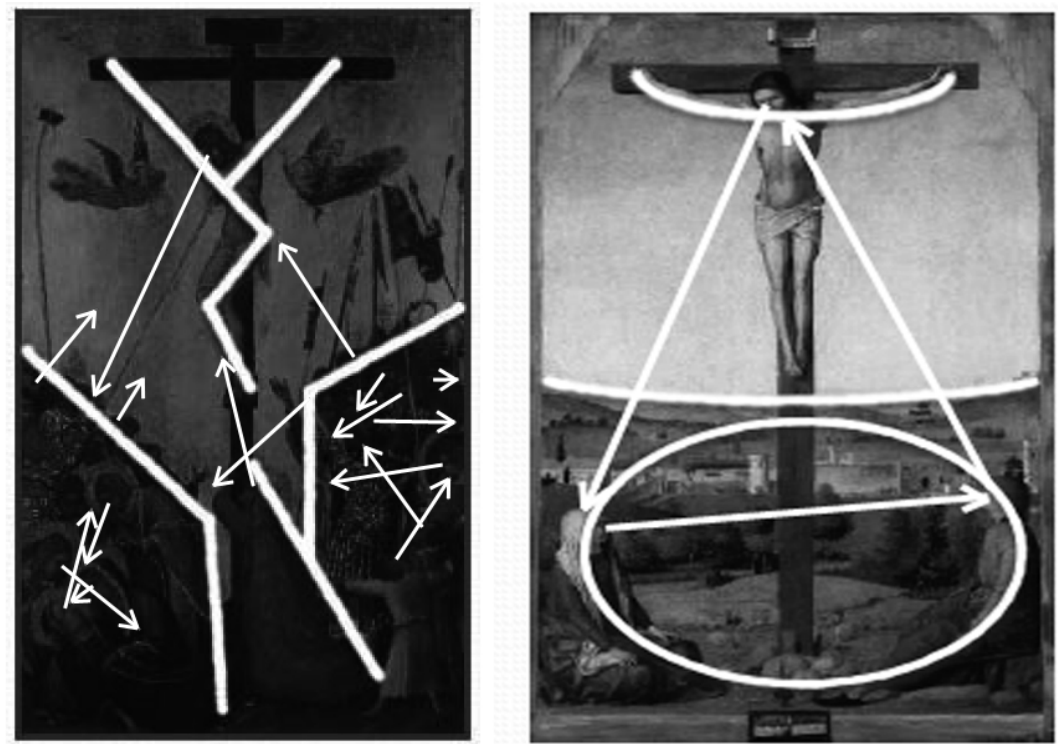

Figure 3: Arrows delineate gaze lines
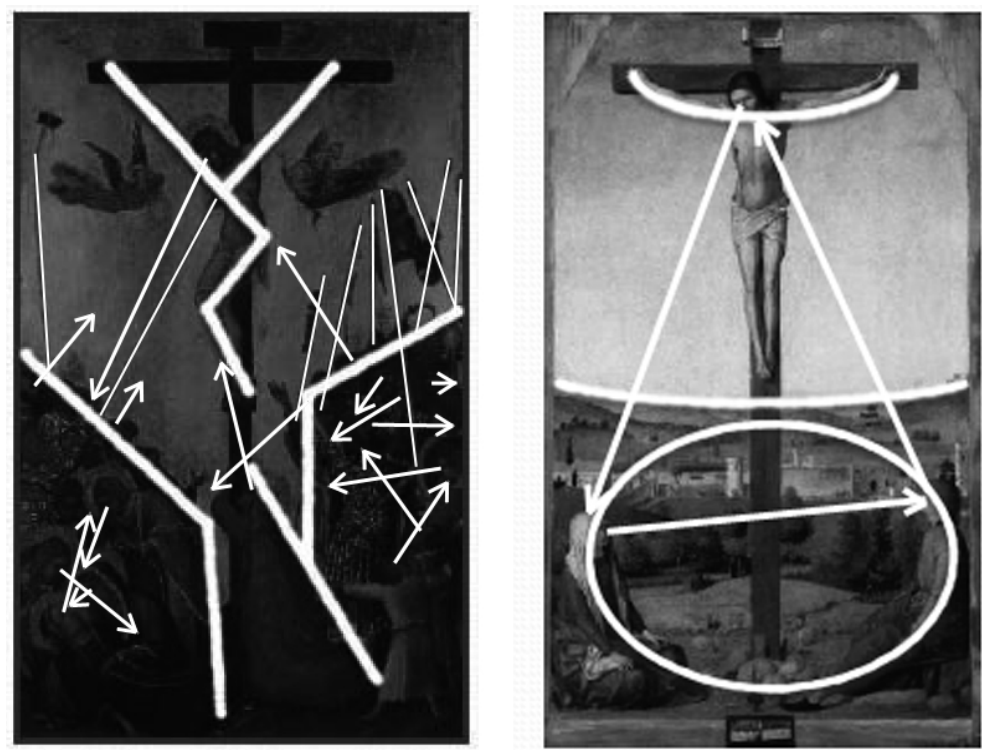

Figure 4: Crucifixion scenes with lines for lances and flag poles added

Missy Elliott's »X-Tasy« will exemplify such musical forces. The lyrics suggest that the song is a depiction of the effects of the drug MDMA, which produces a distortion of real conditions and leads to an uncontrolled willingness to suspend better judgment: »Mmm, ecstacy - it enhances your most inner desire to become more free with your guts and feelings « (spoken introduction); »I'm willing to do all the things I said I wouldn't do (chorus). Backward drums, a trope for unreal conditions since the Beatles' »Strawberry Fields Forever « (1967), appear along with a highly compressed drum machine and vocals with pronounced phasing, reverb and echo, cinematic isomorphs for hazy vision and distorted reality for half a century. In this atmo- 
sphere, the stuttered rearticulation of vocal syllables, heavy breathing, and moaning all suggest a fantasy of sexual abandon. This demonstrates the sort of correspondences one can draw between cross-modal events: blurry sound possessing characteristics of blurry vision and weakened consciousness, and free vocalizations suggesting a loss of control.

But we can also use this passage to demonstrate Arnheim's emphasis of directed structural tension. Shown in Figure 5 is the vocal line in the opening half of the first verse. Above a chromatically lascivious groove that prolongs a tonal center of $F$, Elliott issues an invitation that features two recurring pitches, $G$ and $B$-flat both of which are neighbors to members of tonic harmony. Note how her vocal line divides registrally into two hypnotically repeated events: the upper-voice $F$ decorated by its complete upper neighbor, and a metrically stronger inner-voice $C$ that moves to its nonresolving lower neighbor, B-flat. The F-G-F contour is marked by directed tension (shown in the figure by downward-pointing arrows) created by principles of consonance and dissonance that express conformity in the resolution of dissonant $G$ back into chord root and tonal center, $F$. The lower B-flat defies convention by not resolving back into the stable tone it decorates, an interruption suggested in the notation by the blocking force that restricts a returning upward movement from B-flat. ${ }^{5}$ The unrelenting repetition and strong syncopated accent suggest an unmoving stubbornness in the B-flats, especially in contrast against the higher well-behaved neighbor Gs. Given that such divided registers have been shown in much of my own work to suggest outer and inner manifestations of a subject's divided persona, one might construe the complete upper voice as a proper outward invitation and the insinuative inner voice as an arresting suggestion of socially restricted pleasures. A non-harmonic tone's position vis-à-vis conformity, based on underlying structural tension, relates isomorphically to differing modes of address, one overt and polite, but the other hidden and suggestive.

5 The musical qualities of directed and blocking forces (especially as conceived in relation to bodily experience) form the central topic of several essays (Brower 1997-98, Johnson 1997-98, Larson 1997-98, and Saslaw 1997-98) that appeared in the 1997-98 volume of Theory and Practice. Also see Johnson 1987, and Larson 2002 and 2004. 

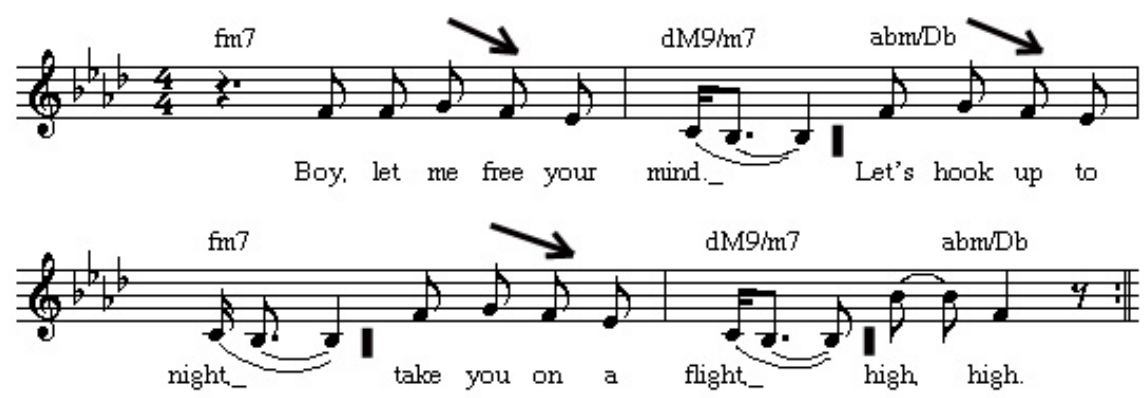

Figure 5: Opening of first verse, Missy Elliott, »X-Tasy« (2001), with indicators for gravitational and blocking forces

Such isomorphic connections between a representation and its object suggest what Charles $\mathrm{S}$. Peirce has labeled the iconic sign, a function depending upon a shared likeness of structures between signifier and signified. Musicians including Jean-Jacques Nattiez, Robert Hatten, Naomi Cumming, Raymond Monelle and David Lidov have worked from Peirce's distinction between iconic, symbolic and indexical signs. ${ }^{6}$ Wagnerian Leitmotivs and Leonard Ratner's classification of eighteenth-century musical topics have been seen as sometimes iconic (when depending upon a shared likeness of structure) and sometimes merely symbolic (when linked to objects by arbitrary convention). ${ }^{7}$ The indexical function indicates by non-arbitrary linkage to another object or state.

Randy Newman's sneering "Piece Of The Pie « will illustrate all three forms of sign. A snare roll introduces piccolo, staccato trumpets and trombones over an oom-pah bass, all of which immediately put one in the mind of a parade. The parade image is fitting, as this song is an ironic celebration of an oblivious patriotic fervor. The idea of a parading band is suggested by the instrumentation, an indexical signifier; the piccolo, for instance, carries no message here other than indexing the band's scoring. The march carries strong iconic resemblances to the dynamism of the bravado that underlies nationalism. But a contrary iconic signifier is also heard. As can be seen in Figure 6, taken from the first verse, a texture of decadent bitonality and "wrong notes" - which out-Iveses that composer's own song, »The Circus Band « - parallels the subtext of society gone wrong, its fervor a blind one.

6 Peirce's writings from 1867 through 1908 have been collected in Peirce 1994. For musical interpretations of Peirce's sign set, and those explored in Saussure 1916, see most particularly Hatten 1982: 33-62; Nattiez 1990; Cumming 2000: 68-163; Monelle 2000: 14-17; and Lidov 2005: 6-9.

7 Ratner (1985), rooted in the rhetorical studies of the 17th and 18th centuries, serves as a compendium of classical-era musical tropes as topics; among the many key comments on this work are passages in Agawu 1991: 7 and 23-30, and Monelle 2000: 14-17. 


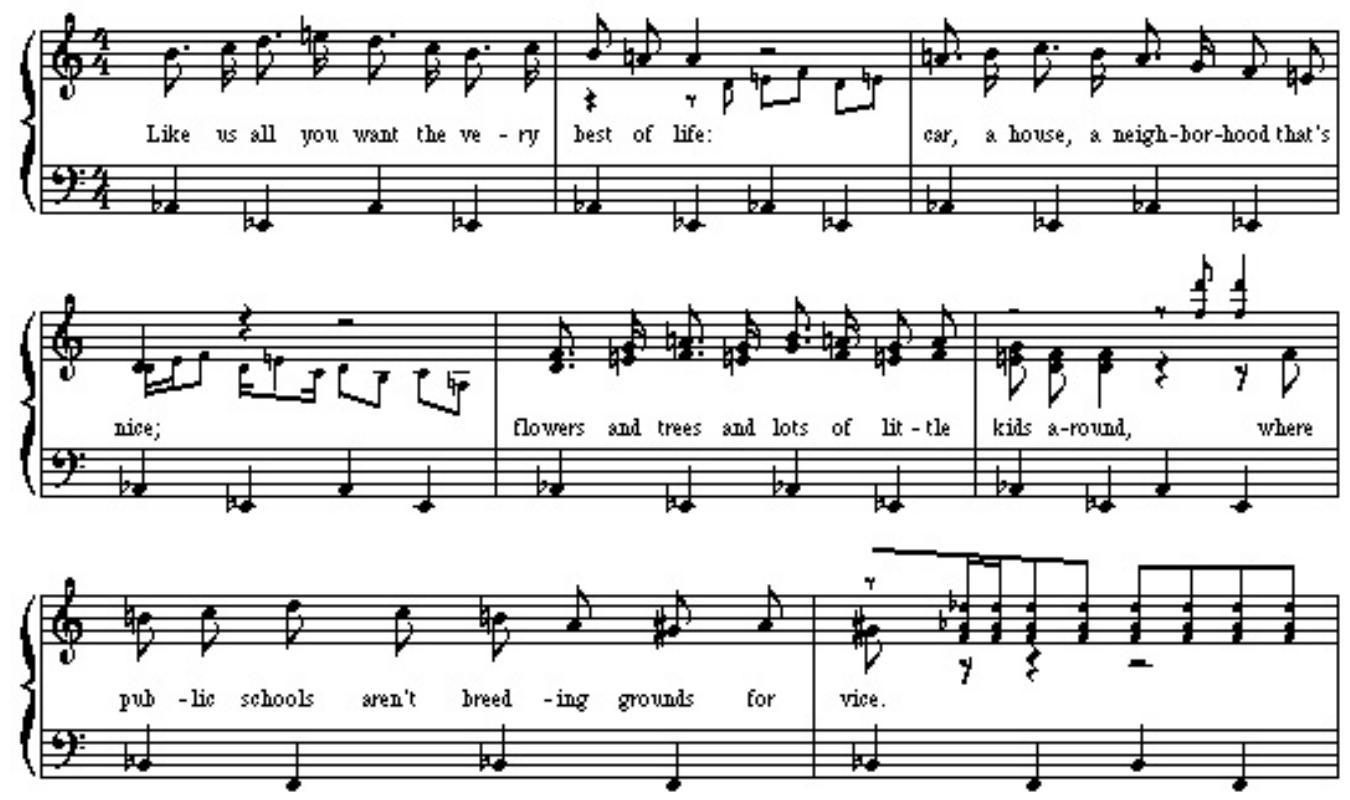

Figure 6: Excerpt from first verse of Randy Newman, »Piece Of The Pie« (2008); cues represent selected instrumental parts

(Note how the bass line moves from a grounding in A-flat to one in B-flat, while the rest of the texture follows a long-sustained $V^{7}$ of $C$ major with a major triad a tritone away, on D-flat). A symbolic quality is found later, in the anthem that bursts forth from the song's third verse, performed by a unison male chorus that responds with outrage (»That's not true!«) to the singer's impudent questioning of the patriotism of John (Cougar) Mellencamp, folk hero and singer of »Our Country«, the song used in the 2006 TV ad campaign for the Chevy Silverado Truck:

Verse 3: $\quad$ There's a famous saying someone famous said:

>As General Motors goes, so go we all.<

Johnny Cougar's singing it's their country now;

He'll be singing for Toyota by the fall.

Pre-chorus: That's not true! John's a patriot; he's not like you, he's a . . .

Chorus: Jesus Christ, it stinks here low and high,

Some get rich and others just get by ... «

(Randy Newman: »Piece Of The Pie«, 2008).

Here, the men's unison retort is accompanied by excited trills in the piccolo, above symbolic wordless backing vocals from women that (all together, men and women) suggest a conventional stylistic reference to an anthemic greek chorus just as would, say, the quotation of a chorale tune in Berg. There is no implication that a chorus of singers is actually parading along with the band, and it is not lining the route; its sound is symbolic. In 
such multiple ways, a celebratory march is given a culturally coded ironic cast, lampooning thoughtlessness on parade.

An important component of song repertoire is the poetic text, creating with music a hybrid art, as it's called by Jerrold Levinson, Peter Kivy and Stephen Davies. ${ }^{8}$ The cross-modal potential of words set to music has inspired Nicholas Cook's study of meaning in multi-media forms (1998), has had direct relevance to rock scholars in Dai Griffiths's suggestions for reading lyrics, and has been a core interest of mine for some time. Crossmodal transference also has more subtle sides, as in Kivy's consideration of program music, Lawrence Kramer's readings of poetic shades in purely instrumental music, and Cumming's determination that music contains within it the qualities of the human voice, but we are here engaged with the conceptual blending brought on by songs that offer poetry in conjunction with harmony.

Let us investigate the dialogue of text and music through Wilco's »Either Way.« Figure 7 presents a voice-leading analysis of the song's paired verse and refrain. The simple folk-like repeated alternation of diatonic $\mathrm{I}$ and $\mathrm{ii}^{7}$ chords in $D$ in the verse is answered by a refrain in which a chromatically expanded minor dominant (moving to $A$ in the bass) is answered by a prolonged flat-VI chord, which resolves directly to tonic as a neighbor harmony that forces mode mixture upon the composed-out third scale degree, as the alto-register F-natural momentarily replaces F-sharp. The 5-7, 5-7 linear intervallic pattern embedded within ranges far afield. While we can thus recognize with some clarity the refrain's pitch relationships, it is more difficult to closely parse the »meaning « of such unusual tonal behaviors. The D-major tonic is the goal of the phrase, but following the verse's dominant preparation $\left(\mathrm{ii}^{7}\right)$, two attempts are required to achieve that goal, through the 5-7 sequence. The inner-voice pitch-class pairs E-flat and E-natural, and then F-natural and F-sharp, are considered as alternative scale members in these gestures. Two alternative approaches to tonic, neither passing through an explicit functional dominant, and each path exposing chromatic alternatives. The lyric helps us interpret these somewhat ambiguous sets of alternatives:

8 The long-invoked question as to which artform, music or verbal language, had primacy in song was addressed through the notion of hybridity through the entire second chapter of Levinson 1990: 26-36. This formulation is adopted in Davies 1994: 114-117, and Kivy 2007: 201. 
»Maybe the sun will shine today,

The clouds will blow away.

Maybe I won't feel so afraid;

I will try to understand either way«

(Wilco: »Either Way«, Verse 1, 2007).

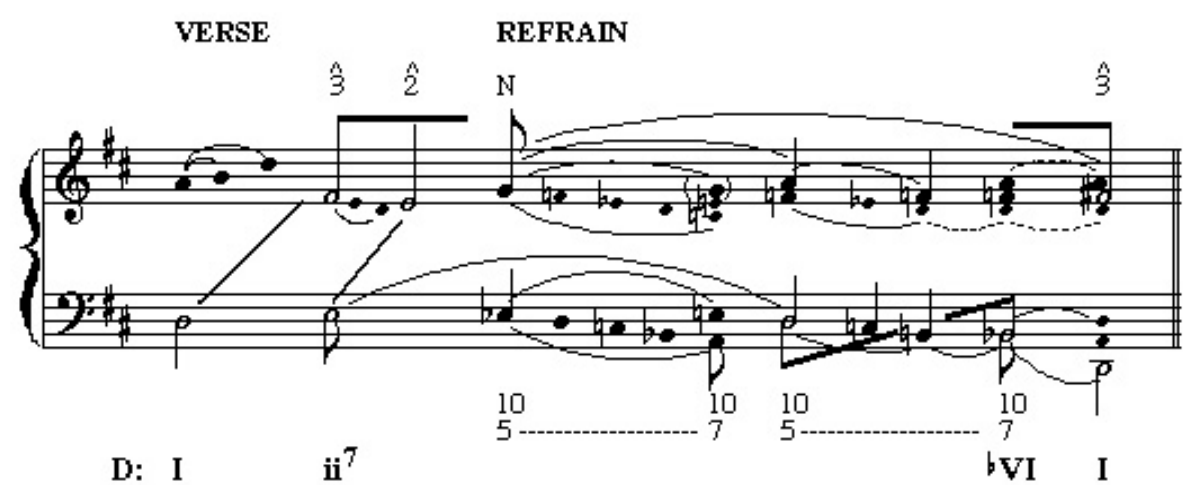

Figure 7: Voice-leading analysis of verse / refrain of Wilco, »Either Way« (2007)

In the first part of the phrase, the singer considers two pairs of potential opposing outcomes: sunshine or clouds, confidence or fear. (Succeeding verses present similar perplexities.) In the problematic refrain that completes each verse, the singer expresses a desire to try to understand what happens, »either way. « Thus, it seems natural to map the singer's alternative conceptual paths onto the divergent musical ones, and the professed difficulty in understanding seems logically tied to the harmonic ambiguity. In this case, the meaning present in lyrics helps us interpret a possible meaning within the accompanying musical structure.

This and similar arguments should lead the critical listener to wonder how appropriate might be the interpretation we have settled upon. Is this or is any particular understanding broadly acceptable, suitably free of affectation? Following Nelson Goodman's note that metaphor involves a resistance as well as an attraction between a pairing of terms from crossed artforms, Kivy has a wonderful phrase, »aesthetic recalcitrance inherent differences that divide different modalities of artistic expression, including that between words and music. ${ }^{9}$ In the past, Cook (1995-1996: 29)

9 Goodman (1968: 69f.) discusses the relation of resistance and attraction in metaphorical relations. Kivy exemplifies aesthetic recalcitrance thus: because musical bird calls closely mimic the sounds of their objects with a similar means of tone production, there is no metaphorical distance, no recalcitrance in portrayal or appreciation. The sculpturing of pillows in marble, however, requires in a way both an imaginative leap on the sculptor's part and a suspension 
has branded one of my interpretations of text-music relations as a product of »sleight of hand«, an analogy I find delightful. The listed works of Roland Barthes, Kofi Agawu, Allan Moore, Arnheim, Nattiez, Hatten, and Lidov speak most clearly on the need for the most general possible interpretation of the meaning of a musical event, and on the necessity of abiding by culturally agreed upon correspondences. Kendall Walton (1990: 60), as a negative example, says it would be an inappropriate interpretation of the subject of Georges Seurat's painting, La Grande Jatte, to speak of hippos. His exercise, of course, frames the extreme; we are regularly confronted with far greyer areas than the hippo position. The other sides that frame the problem of appropriateness might be Milton Babbitt's insistence on rigor, Guck's rehabilitation of the incorrigible (Guck 1994a), and Lydia Goehr's consideration of the politics involved. All of these issues relate to the weak identity of the artwork, its openness, its scriptibility, or its inexhaustible interpretability, as phrased by Hans-Georg Gadamer, Umberto Eco and Barthes, and discussed by John Neubauer. Moore (1993: 11, 154-160) writes of the difficulty of establishing unequivocal musical meanings in individual songs, and he might well write of the implausibility of any interpretation gaining universal acceptance.

Lawrence Kramer offers some helpful guidance. First, it should be noted that in the face of those who hold that music cannot represent ideas with the specificity that language can, Kramer (2006: 8) reminds us that meanings expressed in the art of poetry may often be extraordinarily suggestive of multiple interpretations - that there is much »unruly« meaning in verbal poetry. He finds that musical complexity tends to yield suggestions of a sort of pre-verbal meaning and that whereas the identification of musical tropes can be a »catch-as-catch-can« occupation, the analyst is advised to seek out the object's most complex moments, its most problematical spots, for windows into potential hermeneutic meanings. "Interpretation, « he says, »takes flight from breaking points, which usually means from points of under- or overdetermination: on the one hand, a gap, a lack, a missing connection; on the other, a surplus of pattern, an extra repetition, an excessive connection « (Kramer 2006: 12). In the Seurat mentioned by Walton, a viewer might see the pointillistic brushwork as a breaking point underdetermining representation, and consider a possible role for it in emphasizing the play of broken afternoon light upon deemphasized objects. All of Kra-

of the perceiver's disbelief based on the material distance between the metaphorical terms of stone subject and feathery object. Kivy (1984: 101) says, »the medium of musical sound holds interest for us as a medium of illustration not in spite of its aesthetic recalcitrance but, in effect, because of it«. 
mer's characteristics would seem to apply at once to the chromatic refrain of Wilco's »Either Way, « supporting our choice of entryway into our interpretation there.

Another way to look at these breaking points is to consider the question of binary oppositions and markedness, a primary concern of Hatten's work. ${ }^{10}$ The wrong notes in Randy Newman stand out as marked, as errant substitutes for normally functioning tones, and given their context can be taken as stylistic markers for an Ivesian Americana - of course, all the wrong notes are right. Such binary oppositions as wrong vs. right can play out in larger-scale arenas than note-to-note relations. Coldplay's »Square One« (2005) ends on an apparent IV chord. In fact, the song never seems to find rest in its tonal center: the verse (as at 0:42), chorus (1:36) and coda all conclude with different non-tonic endings. The singer is lost, paralyzed, stuck at »square one «. He is unable to progress to a goal. He asks for a compass, asks for a map. »I can't get back, « he sings. Clearly, the lack of resolution in tonic is a large-scale marked tonal characteristic in binary opposition to the position-confirming security of a normally occurring authentic cadence.

Kramer's notion of »a surplus of pattern « suggests the related quandary afforded by ambiguity. When a surplus of information leads to incompatible and imbalanced factors competing for acceptance in a unified interpretation, the perceiver seeks a bearing along a continuum ranging from contradictory complexity to perfect order. Leonard B. Meyer, Carl Schachter, Eco, Arnheim, Nattiez, Agawu, and Lidov speak to the relation between chaos and order in a listener's cognition of musical ambiguity, a condition that is occasioned by the comparison of equally compelling alternative meanings. ${ }^{11}$

10 Monelle's adoption for semiotics of markedness theory, in turn derived from "Derrida's deconstruction of binary oppositions in culture «, is described in Hatten (2004: 8f.), and forms an important basis of this book's approach.

11 Meyer (1956: 26f.; see also 37 and 51) relates his theory of musical expectation to qualities of ambiguity: »The antecedent stimulus situation may be such that several consequents may be almost equally probable. [...] The mind rejects and reacts against such uncomfortable states and, if they are more than momentary, looks forward to and expects a return to the certainty of regularity and clarity«. Arnheim (1966: 124) on the general nature of the perception of incompatible objects: »Order and complexity are antagonistic. [They,] however, cannot exist without each other - complexity without order produces confusion; order without complexity produces boredom «. Elsewhere, Arnheim (1974: $14,19)$ revisits the question, finding that complexity involves multiple »incompatible conceptions, " as when a balance of multiple percepts creates ambiguity. Nattiez (1990: 83) cites Eco's theory of the open work as a path to its fundamentally ambiguous message, "a plurality of signifieds that coexist within a single signifier «, suggesting that an artwork's essential goal is to have its inde- 
Amy Winehouse's »Wake Up Alone « is instructive for its presentations of multiple localized tonal centers, each vying for centricity. As shown in Figure 8, the G-major song surprises with its large-scale tonicization of the major submediant, E major, itself opening with a tonicization of its own submediant, C-sharp minor, which area leads off the beginning of the verse with its own submediant chord, A major, to which we return following the trailing-off cadences on $F$ (from the end of the first verse, at 0:55) and $E$ flat (from the end of the chorus, at 1:49-1:51). The F chord is a tritone substitution for $\mathrm{V}$ of $\mathrm{E}$, a perfect emblem for the 180 degree turn that Winehouse narrates.
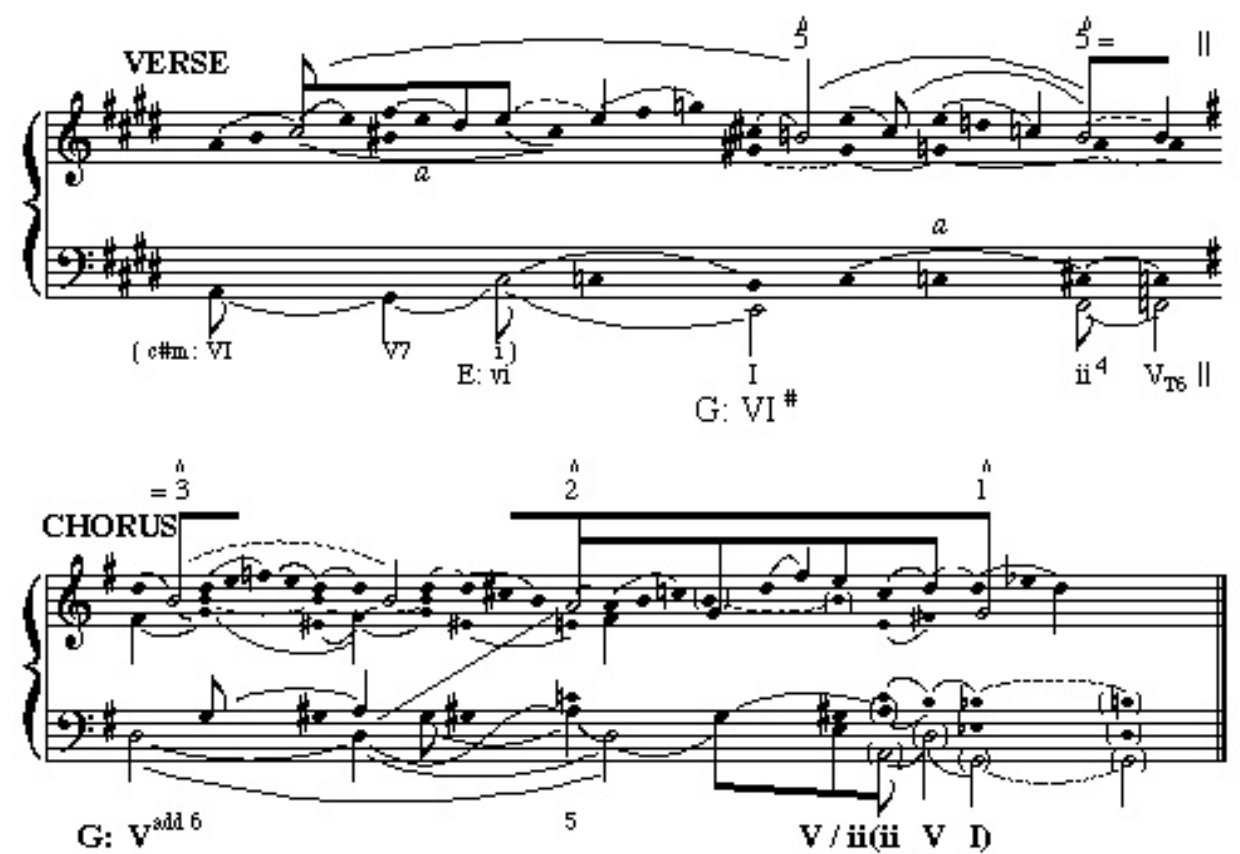

Figure 8: Voice leading in Amy Winehouse, »Wake Up Alone« (2006)

Despite the complex of distantly related tonal centers that cause frequent reinterpretation of the large-scale structure in "Wake Up Alone , an imposing order can be perceived not only in the reflexive nesting of submediant chords (vi within vi within VI), but in the large-scale voice leading of the chorus, throughout which $G$ reigns. In Winehouse's lyric, she paints herself as seeking ways to distract herself from an underlying despondency cleaning the house, hoping not to resort to alcohol; when she falls into depression, she rights herself with the 180 degree turn.

terminate confusion interpreted by the perceiver. Agawu (1994) and Schachter (1999) both instruct the music analyst as to how to consider the strengths of competing meanings. See also Lidov 2005: 21. 
Verse 1: „It's okay in the day, I'm staying busy;

Tied up enough so I don't have to wonder where is he.

Got so sick of crying, so just lately,

When I catch myself I do a 180.

Verse 2: I stay up, clean the house,

At least I'm not drinking.

Run around just so I don't have to think about thinking «

(Amy Winehouse: »Wake Up Alone«, 2006)

The verse's shifting tonal centers portray the contradictory complexity of the singer's short-lived attempts at self-distraction.

But how could one determine a single tonal center in the abrupt truckdriver's modulations of the Flaming Lips' »Haven't Got A Clue«? The vocal melody and chords for the verse are indicated in Figure 9; note how the tonal center fluctuates between $G$ and A-flat. It seems that the song's meaning must lie in the irreducibility of the two points of tonal reference; the bipolar structure depicts an attempt to trick the singer into accepting a phony tonic, but he is not buying. Any idea of a single overriding tonal center should be found inappropriate, resting on a simulacrum of centricity; no overall structural priority could be persuasively argued.

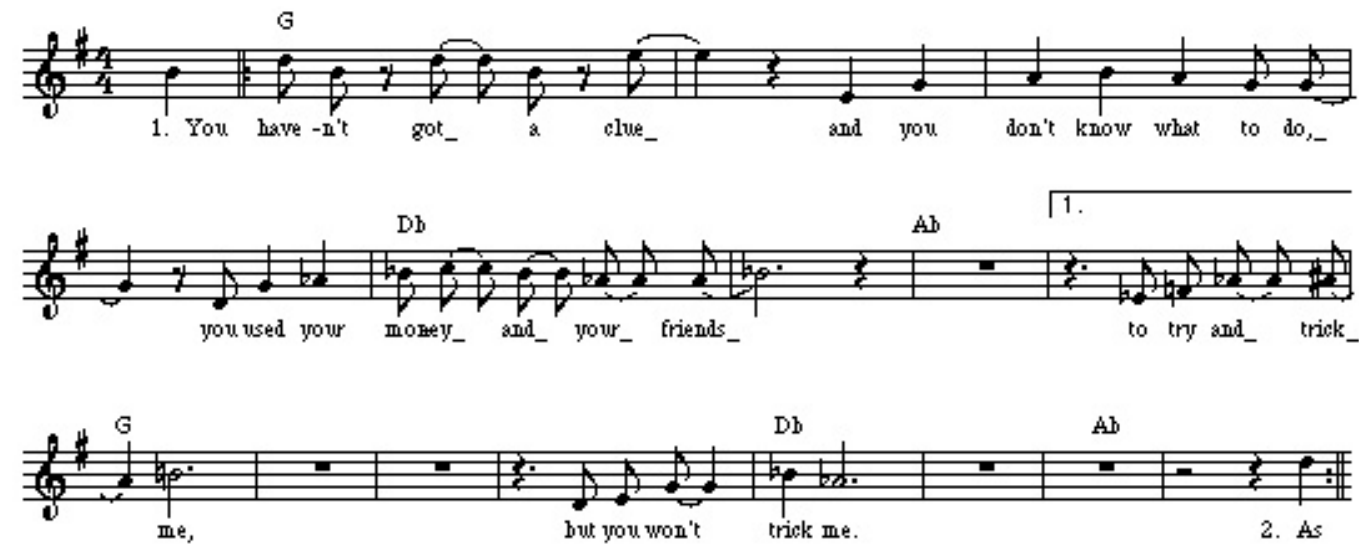

Figure 9: Vocal part and chords for the first verse, The Flaming Lips, »Haven't Got A Clue $\ll(2006)$

Such a comparison of competing factors also plays out in another dimension: that relating the individual artwork to a higher-level archetypal system that functions as an environmental field of norms. Among other comparisons, the possibility of ambiguously related facts within a single work is addressed in Ferdinand de Saussure's syntagmatic domain, whereas the comparison of an idiosyncratic statement to a regularized cultural language is a paradigmatic 
exercise. ${ }^{12}$ Patrick McCreless, John Covach, Hatten, Nattiez, Agawu, Kivy, and Moore are helpful in clarifying this relationship and providing useful musical illustrations. ${ }^{13}$ An expansion of this relationship as outlined in Figure 10 would recognize three basic levels of order, which would also permit of innumerable suborders: an ideally fixed high-level tonal system, varying midlevel stylistic languages and practices, and surface-level individual works and closely circumscribed groups of works. In addition to the relationships shown, individual works may of course also partake of more than one style, or even contain passages that borrow from outside the tonal system entirely.

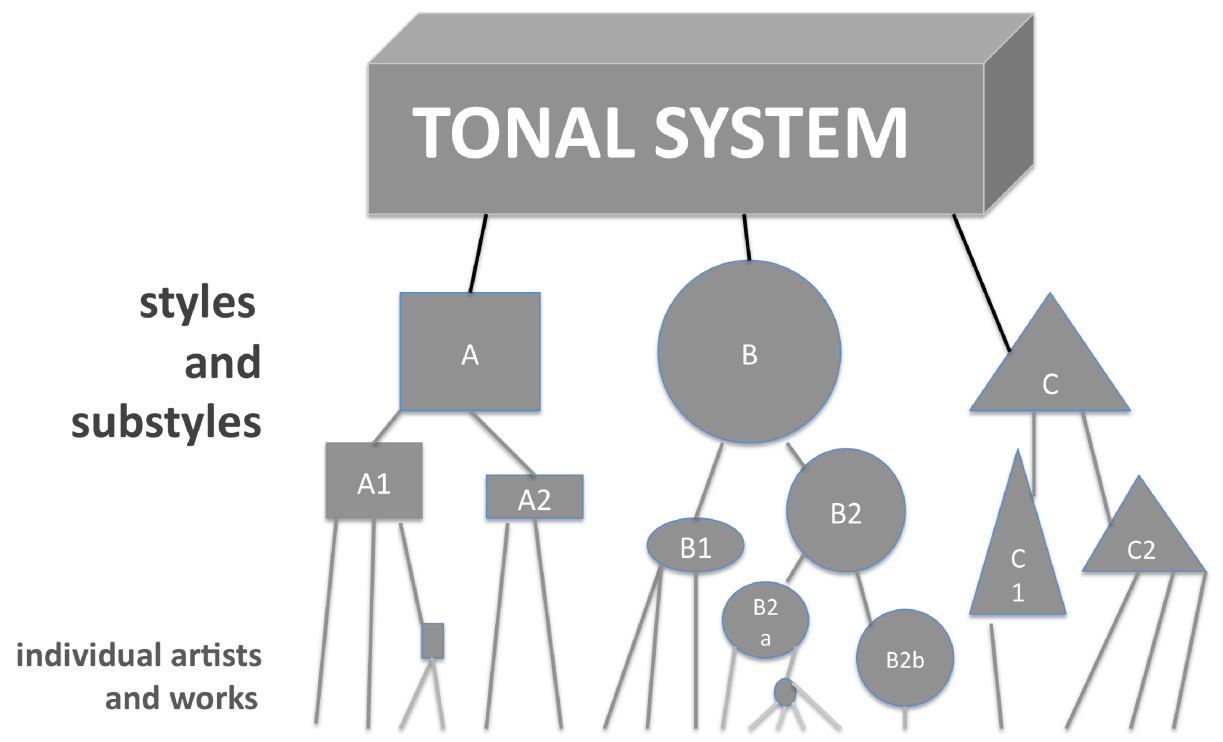

Figure 10: A network modeling the relationships between individual instantiations (bottom) and an abstract contextualizing system (top), as applied to music

The play of expected resolutions of non-harmonic tones can exemplify these three positions. Events such as suspensions, passing, and neighbor tones are

12 The poststructuralist view that contrasting events within a work (which are related to each other along what Saussure labeled the syntagmatic axis) can only be understood in relation to the universe of texts (found along the paradigmatic axis) to which the perceiver relates them, and the systems by which they are understood stylistically, is developed by Saussure, Julia Kristeva, and Barthes. See, for instance, Barthes 1977: 7, and Hatten 1982: 38.

13 Hatten (2004: 117) suggests that tonal and metric systems are environmental fields from which individual musical utterances derive their meaning. McCreless (1988: 1) finds parallels between Barthes' work of 1970 (1975) »and current theoretical views, particularly those of Schenker, on classic tonal works«. See also Nattiez 1990: 5, 9, and 24; Kivy 2002: 151f.; and Agawu 2009: 164f. Moore (2003b: 159) and Covach (2003: 175) apply Saussure's distinctions to the analysis of rock music; Covach (2003: 179f.) uses the term »musical worlding « to denote the identification of a style-defining network to which any seemingly selfstanding piece is bound. 
behaviors regulated in the tonal system, but various tonal styles exhibited in jazz and rock may necessitate adjustments in our expectations as to whether or not conventional behavior will be practiced. Some forms of soft folk-rock, for instance, include suspensions that we do not desire to resolve; the style leads us to not expect adherence to systematic resolution. ${ }^{14}$ An example from 1969 demonstrates this style; the sketch in Figure 11 (from Everett 2007: 148) illustrates the harmony and voice leading in »Lady Of The Island, « by Crosby, Stills and Nash. Note the non-resolving B-flat and F, both of which sustain, usually as non-chord tones, in inner voices through the entire phrase in E-flat major. A given piece, however, may play with this style-based level of expectation with some subtlety, an activity I hear in Bon Iver's »Re: Stacks«, the introductory chord changes of which are given in Figure 12. Here, the guitar's soft folk-rock strumming suggests a stubborn paralysis with its continuous non-resolving suspensions. Both first and fifth scale degrees seem immovable over V, I and IV chords in A major, until a 4-3 resolution at 0:25 surprises with its conventionality, an adherence to norms paralleled in the ultimate 3-4-3 motion over the cadential tonic (at 0:43-0:45). »Re: Stacks« at once exists in the style exemplified forty years earlier by »Lady Of The Island« and comments upon that style.

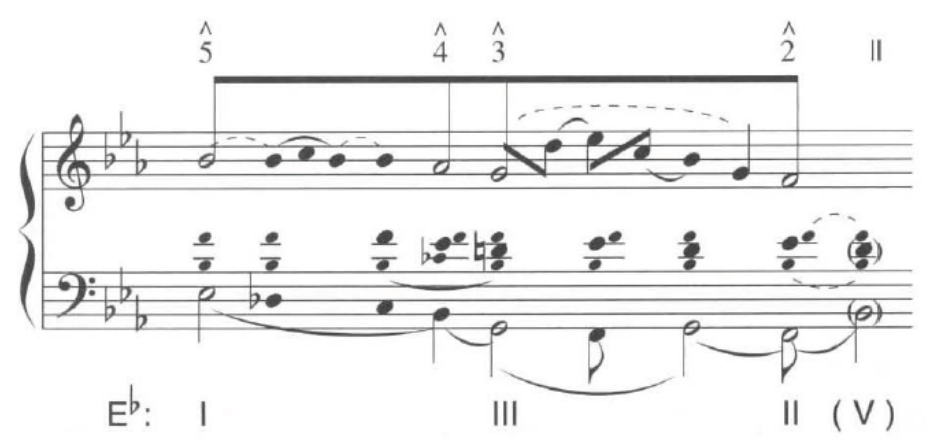

Figure 11: Voice leading in the verse - refrain structure of Crosby, Stills \& Nash, »Lady Of The Island« (1969)

$$
E^{\text {sus } 4}-A-D^{\text {add9 }}-E^{\text {sus } 4}-D^{\text {add } 9}-E^{\text {sus4-3 }}-A-D^{\text {add9 }}-E^{\text {sus } 4}-D^{\text {add9 }} / B-A^{3-4-3}
$$

Figure 12: Bon Iver: »Re: Stacks« (2008), chord changes in ac.-guitar introduction

An understanding of the underlying system is crucial when the individual musical work does not seem to contain sufficient information to allow an interpretation. Often, voice-leading or harmonic events require the listener

14 This is also true of some common-practice styles, as in the songs of Gabriel Fauré. Meyer (1956: 50-71, 135 et passim) and Hatten (1982: viii, 119f.) explore the relationships between deviations from norms, expectation, expression, and ramifications for style analysis. 
to consider what is not present but only implied. We have seen that for Arnheim, the observer's percept is based not only on explicit outlines, but also on the implied dynamic forces that are understood to support and guide them, and which might suggest movement that cannot be captured in the observed medium. Meyer's notions of expectation depend on comparisons against understood but unarticulated norms; Walton adds that implied elements acceptable for consideration in an analysis are those agreed upon by social convention. Eric F. Clarke goes so far as to say that sound is chaos before the perceiver structures it. ${ }^{15}$ Certainly, we are always comparing the text at hand with abstract principles; at times, the gap between the actual and the abstract is large enough that the implied structure shouts across the divide loudly enough to be heard despite its absence. The ending of the chorus in the Winehouse track examined in Figure 8, »Wake Up Alone, « offers a strong example of such an implied function. Here, the empty final cadence consists of the chords A minor (at 1:45), B minor (1:47), and E-flat major (1:49-1:51), where one would expect an arrival of the G-major tonic. I would argue that, as in the jazz tradition, the audible chords manifest upper-voice values only, and would require the addition of an implied bass line of the parenthesized second, fifth and first scale degrees (A, D and G, respectively) to provide the harmonic support that would be proper to a goal-directed tonal system. Another way of saying this is that Winehouse's track substitutes non-functioning chord roots (A, B and E-flat) for those that would have behaved standardly in a $\mathrm{ii}^{7}-\mathrm{V}-\mathrm{I}$ cadence. The resulting hermeneutic effect is one of missed support, a fitting portrayal of dreams that end in rejection... »and I wake up alone «.

One topic not touched on in this essay is perhaps the largest of all - the question as to whether a listener need be consciously aware of any of these operations in forming an interpretation of a song from our chosen repertoire. Does the naive listener possess the competence to make such

15 Arnheim (1974: 12) speaks of »induced structures« by which the perceiver supplies information not present in the object of study, such as meter providing a context for syncopation. Meyer (1956: 130) writes of just such a »structural gap « and also the »delay of closure « as two ways in which a piece of music may represent incompleteness, requiring a listener's intervention. Walton (1990: 142-152) discusses how key elements may often be only implied, so that the perceiver must exercise an Occam's razor of judgment in discerning the most prominent and significant unseen or unvoiced attributes, constructing a social fabric of agreed-upon acceptances that yield to a Mutual Belief Principle. Cook (1998: 3 and 2001: 178 ) also speak to the »mediation of society « in constructing an interpretation of meaning in art. Clarke (2005) extrapolates this view so as to state that all elements of musical sound are chaos before a perceiver begins to interpret them in the context of a systematized environment. 
nuanced decisions? Is there at work a culturally mediated collective unconscious that serves as a silent guide? Fred Lerdahl and Ray Jackendoff, Mark DeBellis, Meyer, Ratner, and Agawu all touch on this and would seem to support the notion that the normal and fully competent appreciation of tonal events is one held even by those blissfully ignorant of the techniques that underlie them. ${ }^{16}$ I would agree with this to a point, adding that the more aware one might be of possibilities and pitfalls, the more nuanced and still more widely acceptable hearing might be obtained. Also not considered here are the entire realms of meaning as related specifically to the composer's or performer's (broadly conceived, as there are many contributors to these tasks in the production of rock music) - as opposed to the listener's process. What I hope we have been able to do is outline a number of approaches and concerns one might bear in mind in constructing an interpretation of what a song might mean, and suggest a few of the many recent musical examples and philosophical sources worthy of study to that end.

\section{References}

Agawu, Kofi. (1991). Playing With Signs: A Semiotic Interpretation of Classic Music. Princeton: Princeton University Press.

Agawu, Kofi (1994). "Ambiguity in Tonal Music: A Preliminary Study."In Theory, Analysis and Meaning in Music,. Ed. by Anthony Pople. Cambridge: Cambridge University Press, pp. 86-107.

Agawu, Kofi (2009). Music as Discourse: Semiotic Adventures in Romantic Music. New York: Oxford University Press.

Arnheim, Rudolf (1966). Toward a Psychology of Art. Berkeley: University of California Press.

Arnheim, Rudolf (1974). Art and Visual Perception: A Psychology of the Creative Eye. Berkeley: University of California Press $\left(2^{\text {nd }}\right.$ ed. $)$.

Arnheim, Rudolf (1986). New Essays on the Psychology of Art. Berkeley: University of California Press.

Babbitt, Milton (1961). »Past and Present Concepts of the Nature and Limits of Music.« In: International Musicological Society. Report of the Eighth Congress New York 1961. Ed. by Jan Larue. Kassel: Bärenreiter, pp. 398-403.

16 Meyer (1956: 31): »though intelligence is clearly and necessarily involved in the perception and understanding of the stimulus situation, the response will probably remain unconscious «. Lerdahl and Jackendoff (1983: 3) discuss how the naïve listener need not be trained to process formal factors unconsciously. Agawu (1991: 3, 7, 49, and 138) finds that although Mozart depended upon his audience's extensive competencies in recognizing exemplars of a rudimentary vocabulary (such as those catalogued in Ratner 1985), these same gestures took on a hidden, cryptic function in the 19th century that need not call up conscious recognition. DeBellis (1993: 277f.) considers different depths of understanding as benefiting the untutored listener. 
Babbitt, Milton (1965). »The Structure and Function of Musical Theory.«In: College Music Symposium 5, pp. 49-60.

Babbitt, Milton (1971). "Contemporary Music Composition and Music Theory as Contemporary Intellectual History. «In: Perspectives in Musicology. Ed. by Barry S. Brook et al. New York: W. W. Norton \& Co., pp. 151-184.

Barthes, Roland (1975). S/Z: An Essay [1970]. Trans. by Richard Miller. New York: Hill and Wang.

Barthes, Roland (1977). Image, Music, Text. Trans. by Stephen Heath. New York: Hill and Wang.

Brower, Candace (1997-98). »Pathway, Blockage, and Containment in Density 21.5. «In: Theory and Practice 22-23, pp. 35-54.

Brower, Candace (2000). »A Cognitive Theory of Musical Meaning. «In: Journal of Music Theory 44:2 (Autumn), pp. 323-379.

Clarke, Eric F. (2005). Ways of Listening: An Ecological Approach to the Perception of Musical Meaning. New York: Oxford University Press.

Cook, Nicholas (1995-1996). »Music Minus One: Rock, Theory and Performance.« In: New Formations 27 (Winter), pp. 23-41.

Cook, Nicholas (1998). Analysing Musical Multimedia. Oxford: Clarendon Press.

Cook, Nicholas (2001). »Theorizing Musical Meaning. «In: Music Theory Spectrum 23:2 (Fall), pp. 170-195.

Covach, John (2003). »Pangs of History in Late 1970s New-Wave Rock.« In: Analyzing Popular Music. Ed. by Allan F. Moore. Cambridge: Cambridge University Press, pp. 173-195.

Cumming, Naomi (1997). »The Subjectivities of >Erbarme Dich<.«In: Music Analysis 16:1 (March), pp. 5-44.

Cumming, Naomi (2000). The Sonic Self: Musical Subjectivity and Signification. Bloomington: Indiana University Press.

Davies, Stephen (1994). Musical Meaning and Expression. Ithaca: Cornell University Press.

Davies, Stephen (1997). »Why Listen to Sad Music if It Makes One Feel Sad?« In: Music and Meaning. Ed. by Jenefer Robinson. Ithaca: Cornell University Press, pp. 242-253.

Davies, Stephen (1999). »Rock versus Classical Music. «In: Journal of Aesthetics and Art Criticism 57:2 (Spring), pp. 193-204.

Davies, Stephen (2003). Themes in the Philosophy of Music. New York: Oxford University Press.

DeBellis, Mark (1993). »Theoretically Informed Listening. «In: The Interpretation of Music: Philosophical Essays. Ed. by Michael Krausz. Oxford: Clarendon Press, pp. 271-281.

Eco, Umberto (1984) [1979]. The Role of the Reader: Explorations in the Semiotics of Texts (Advances in Semiotics). Bloomington: Indiana University Press.

Everett, Walter (1991). »Voice Leading, Register and Self-Discipline in Die Zauberflöte. «In: Theory and Practice 16, pp. 103-126.

Everett, Walter (2005). »Deep-Level Portrayals of Directed and Misdirected Motions in Nineteenth-Century Lyric Song. « In: Journal of Music Theory 48:1 (Spring), pp. 25-68.

Everett, Walter (2007). "Pitch Down the Middle.«In: Expression in Pop-Rock Music: Critical and Analytical Essays. Ed. by Walter Everett. New York: Routledge Press (2nd ed.), pp. 111-174.

Gadamer, Hans-Georg (1960). Wahrheit und Methode. Tübingen: Akademie Verlag. 
Goehr, Lydia (1993). »Music Has No Meaning to Speak Of: On the Politics of Musical Interpretation. « In: The Interpretation of Music: Philosophical Essays. Ed. by Michael Krausz. Oxford: Clarendon Press, pp. 177-190.

Goodman, Nelson (1968). Languages of Art: An Approach to a Theory of Symbols. Indianapolis: The Bobbs-Merrill Company, Inc.

Griffiths, Dai (2003). »From Lyric to Anti-Lyric: Analyzing the Words in Pop Song." In: Analyzing Popular Music. Ed. by Allan F. Moore. Cambridge: Cambridge University Press, pp. 39-59.

Guck, Marion (1994a). »Rehabilitating the Incorrigible.« In: Theory, Analysis and Meaning in Music. Ed. by Anthony Pople. Cambridge: Cambridge University Press, pp. 57-73.

Guck, Marion (1994b). »Analytical Fictions. «In: Music Theory Spectrum 16:2 (Fall), pp. 217-30.

Guck, Marion (1997). »Two Types of Metaphoric Transference.« In: Music and Meaning. Ed. by Jenefer Robinson. Ithaca: Cornell University Press, pp. 201-212.

Guck, Marion (2006). »Analysis as Interpretation: Interaction, Intentionality, Invention. «In: Music Theory Spectrum 28:2 (Fall), pp. 191-209.

Hanslick, Eduard (1854). Vom Musikalsch-Schonen: Ein Beitrag zur Revision der Aesthetik der Tonkunst. Leipzig: Rudolph Weigel.

Hatten, Robert Swaney (1982). Toward a Semiotic Model of Style in Music: Epistemological and Methodological Bases. Ph. D. dissertation, Indiana University.

Hatten, Robert Swaney (2004). Interpreting Musical Gestures, Topics, and Tropes: Mozart, Beethoven, Schubert. Bloomington: Indiana University Press.

Johnson, Mark L. (1987). The Body in the Mind: The Bodily Basis of Meaning, Imagination, and Reason. Chicago: The University of Chicago Press.

Johnson, Mark L. (1997-98). »Embodied Musical Meaning.« In: Theory and Practice 22-23, pp. 95-102.

Johnson, Mark L. (2007). The Meaning of the Body: Aesthetics of Human Understanding. Chicago: University of Chicago Press.

Kivy, Peter (1984). Sound and Semblance: Reflections on Musical Representation. Princeton: Princeton University Press.

Kivy, Peter (1986). »How Music Moves. «In: What Is Music?: An Introduction to the Philosophy of Music. Ed. by Philip Alperson. State College, PA: The Pennsylvania State University Press, pp. 149-63.

Kivy, Peter (1989). Sound Sentiment: An Essay on the Musical Emotions Including the Complete Text of The Corded Shell. Philadelphia: Temple University Press.

Kivy, Peter (2001). New Essays on Musical Understanding. Oxford: Clarendon Press. Kivy, Peter (2002). Introduction to a Philosophy of Music. Oxford: Clarendon Press.

Kivy, Peter (2007). Music, Language, and Cognition and Other Essays in the Aesthetics of Music. Oxford: Clarendon Press.

Kramer, Lawrence (1984). Music and Poetry: The Nineteenth Century and After. Berkeley: University of California Press.

Kramer, Lawrence (1992). »Music and Representation: The Instance of Haydn's Creation." In: Music and Text: Critical Inquiries. Ed. by Steven Paul Scher. Oxford: Cambridge University Press, pp. 139-162.

Kramer, Lawrence (2002). Musical Meaning: Toward a Critical History. Berkeley: University of California Press.

Kramer, Lawrence (2006). Critical Musicology and the Responsibility of Response: Selected Essays. Aldershot: Ashgate. 
Langer, Susanne K. (1957). Philosophy in a New Key: A Study in the Symbolism of Reason, Rite, and Art. Cambridge: Harvard University Press (3rd ed.).

Larson, Steve (1997). »The Problem of Prolongation in >Tonal Music: Terminology, Perception, and Expressive Meaning. «In: Journal of Music Theory 41:1 (Spring), pp. 101-136.

Larson, Steve (1997-98). »Musical Forces and Melodic Patterns. «In: Theory and Practice 22-23, pp. 55-71.

Larson, Steve (2002). »Musical Forces, Melodic Expectation, and Jazz Melody.« In: Music Perception 19:3 (Spring), pp. 351-385.

Larson, Steve (2004). »Musical Forces and Melodic Expectations: Comparing Computer Models and Experimental Results. «In: Music Perception 21:4 (Summer), pp. 457-498.

Lerdahl, Fred / Jackendoff, Ray (1983). A Generative Theory of Tonal Music. Cambridge: MIT Press.

Levinson, Jerrold (1986). "Song and Music Drama.«In: What Is Music?: An Introduction to the Philosophy of Music. Ed. by Philip Alperson. State College: The Pennsylvania State University Press, pp. 284-301.

Levinson, Jerrold (1990). Music, Art, and Metaphysics. Ithaca: Cornell University Press.

Levinson, Jerrold (1993). »Performative vs. Critical Interpretation in Music.« In: The Interpretation of Music: Philosophical Essays. Ed. by Michael Krausz. Oxford: Clarendon Press, pp. 33-60.

Levinson, Jerrold (1997). »Music and Negative Emotion.«In: Music and Meaning. Ed. by Jenefer Robinson. Ithaca: Cornell University Press, pp. 215-241.

Lidov, David (2005). Is Language a Music? Writings on Musical Form and Signification. Bloomington: Indiana University Press.

McCreless, Patrick (1988). »Roland Barthes's S/Z from a Musical Point of View.« In: In Theory Only 10:7-8, pp. 1-29.

Meyer, Leonard B. (1956). Emotion and Meaning in Music. Chicago: University of Chicago Press.

Monelle, Raymond (2000). The Sense of Music: Semiotic Essays. Princeton: Princeton University Press.

Moore, Allan F. (1993). Rock: The Primary Text. Buckingham: Open University Press.

Moore, Allan F. (Ed.) (2003a). Analyzing Popular Music. Oxford: Cambridge University Press.

Moore, Allan F. (2003b). "Jethro Tull and the Case for Modernism in Mass Culture.« In: Analyzing Popular Music. Ed. by Allan F. Moore. Cambridge: Cambridge University Press, pp. 158-172.

Nattiez, Jean-Jacques (1990). Music and Discourse: Toward a Semiology of Music. Trans. by Carolyn Abbate. Princeton: Princeton University Press.

Neubauer, John (1992). »Music and Literature: The Institutional Dimension.« In Music and Text: Critical Inquiries. Ed. by Steven Paul Scher. Oxford: Cambridge University Press, pp. 3-20.

Newcomb, Anthony (1984). "Sound and Feeling." In: Critical Inquiry 10 (June), pp. 614-643.

Peirce, Charles S. (1994) [1867-1908]. Peirce on Signs: Writings on Semiotic. Ed. by James Hoopes. Chapel Hill: North Carolina Press.

Pratt, Carroll C. (1931). The Meaning of Music: A Study in Psychological Aesthetics. New York: McGraw-Hill Book Company.

Ratner, Leonard (1985). Classic Music: Expression, Form, and Style. New York: MacMillan Publishing Company. 
Saslaw, Janna K. (1997-98). "Life Forces: Conceptual Structures in Schenker's Free Composition and Schoenberg's The Musical Idea. "In: Theory and Practice 22-23, pp. 17-33.

Saussure, Ferdinand de (1974) [1916]. Course in General Linguistics. Trans. by Wade Baskin. London: Fontana / Collins.

Schachter, Carl (1999). »Either/Or.«In: Unfoldings: Essays in Schenkerian Theory and Analysis. Ed. by Joseph N. Straus. New York: Oxford University Press, pp. 121-133.

Walton, Kendall L. (1988). »What Is Abstract About the Art of Music?« In: Journal of Aesthetics and Art Criticism 46:3 (Spring), pp. 351-364.

Walton, Kendall L. (1990). Mimesis as Make-Believe: On the Foundations of the Representational Arts. Cambridge: Harvard University Press.

Walton, Kendall L. (1993). "Understanding Humour and Understanding Music.« In: The Interpretation of Music: Philosophical Essays. Ed. by Michael Krausz. Oxford: Clarendon Press, pp. 259-269.

Walton, Kendall L. (1997). "Listening with Imagination: Is Music Representational?« In: Music and Meaning. Ed. by Jenefer Robinson. Ithaca: Cornell University Press, pp. 57-82.

Zuckerkandl, Victor (1956). Sound and Symbol: Music and the External World. Princeton: Princeton University Press.

\section{Discography}

Bon Iver (2008). »Re: Stacks. On: For Emma, Forever Ago, 4AD CAD2809.

Crosby, Stills \& Nash (1969). "Lady Of The Island. On: Crosby, Stills \& Nash, Atlantic SD 8229.

Missy Elliott (2001). »X-Tasy.« On: Miss E... So Addictive, Elektra 62639-2.

Newman, Randy (2008). "Piece Of The Pie.« On: Harps And Angels, Nonesuch $122812-2$.

The Flaming Lips (2006). »Haven't Got A Clue«« On: At War With The Mystics, Warner Bros. 49966-2.

Wilco (2007). »Either Way. « On: Sky Blue Sky, Nonesuch 131388-2.

Winehouse, Amy (2006). »Wake Up Alone.« On: Back To Black, Island 171 304-1.

\section{Abstract}

For millennia, philosophers and musicians have pondered how meaning can be represented in music. Rock music of the first ten years of the new millennium has included a great deal of experimental work that exercises a strong interest in expressive uses of tonal functions that may be interpreted as underscoring such themes in the songs' poetic texts as paralysis, temptation, the consideration of alternatives, and cultural dehumanization. This essay aims to suggest how such themes are represented in recordings by Missy Elliott, Randy Newman, Wilco, Amy Winehouse, the Flaming Lips and Bon Iver, with arguments contextualized by relevant theoretical writings. 